Check for updates

Rochester, UK

Nadra.Ahmed@nationalcareassocia tion.org.uk

Cite this as: BMJ 2021;374:n1902

http://dx.doi.org/10.1136/bmj.n1902

Published: 05 August 2021
COVID-19

\section{Commentary: Mandatory covid vaccination blames individual care home workers for government failures}

\section{Compulsory jabs detract from the crucial problems of underfunding and workforce shortages, says Nadra Ahmed-and if care home staff leave, it will increase pressure on the NHS}

\author{
Nadra Ahmed chair, National Care Association
}

Before covid, independent analyses had found the UK care home sector to be in a "fragile" state. ${ }^{12}$ Successive governments have ignored chronic underfunding and a worsening staff recruitment crisis, while clients' care needs grow. Now covid has left social care providers battling for survival to provide support for some of the frailest members of our society.

As the pandemic took hold the NHS was given unconditional support to respond. Meanwhile, the social care workforce was left to continue delivering community support despite insufficient personal protective equipment and unsafe discharges from hospitals. Care home staff, like our NHS colleagues, work on the front line, but there was no cry to "keep them safe," no "protective shield" around our services. In return for care staff's dedication, the prime minister saw fit to blame excess deaths in care homes on poor infection control, which outraged the sector. $^{3}$

As care services continued to work hard to stabilise and move forward, on 14 April 2021-less than three months after covid vaccines became available-the government embarked on a consultation to make vaccination a condition of employment in care homes. Despite most (57\%) of the 135000 respondents to the government's consultation opposing mandatory vaccination of staff, with clients and families mostly opposed, the government has pushed ahead with this policy. ${ }^{4}$

Our sector supports people when they are at their most vulnerable, and of course we share the ambition to have a fully vaccinated workforce. But we already have over $87 \%$ of staff and $95 \%$ of residents vaccinated at least once in England-a figure that rises daily. ${ }^{5}$ The figures in London are much lower, however-and herein lies the challenge.

\section{Unvaccinated visitors}

Community transmission remains prevalent, and we know that even vaccinated staff can carry the virus, as can unvaccinated visitors including loved ones and healthcare workers. All health and care services and staff coexist to support patients and clients. Making vaccines mandatory for a part and not the whole makes no sense. Our workforce could walk out of our services and take jobs straight away in the NHS, while social care residents will access treatment, should they need it, from healthcare workers who may be unvaccinated.
We have an exhausted and anxious workforce who, through this new legislation, are being targeted as the root cause of the spread of infection, such that they must have their employment conditions amended. Where is the consideration for alleviating real anxieties about adverse effects from new vaccines? We have a predominantly female workforce who may feel challenged by some of the assumptions relating to childbearing, as well as a considerable number of staff from ethnic minority communities who may have concerns about vaccines embedded in their culture. This is not an ultimatum that staff need.

\section{Unsustainable services}

Care homes have a growing staffing crisis, with over 112000 vacancies and the need for an additional 500 ooo care workers in the next decade or so. ${ }^{6}$ The most dangerous assumption is that staff who walk out will be easily replaced: if staff who have not yet had a vaccine were to leave-potentially an additional $13 \%$-care services would be unsustainable.

Mandatory vaccination of care home workers highlights that social care is always seen as the problem, never the solution. Chronic underinvestment has had a direct impact on the sustainability of services, which has been further eroded by the pandemic. The unintended consequence of this legislation will be greater pressure on the NHS if we cannot staff our services.

Competing interests: I have read and understood BMJ policy on declaration of interests and have no relevant interests to declare.

\section{Provenance and peer review: Commissioned; not externally peer reviewed.}

Care Quality Commission. State of care 2019-20. 16 Oct 2020 www.cqc.org.uk/publications/major-report/state-care

LaingBuisson. UK healthcare market review. 32nd ed. 2020.

Coronavirus: Boris Johnson criticised over "cowardly" care home comments. BBC News 2020 Jul 7. https://www.bbc.co.uk/news/uk-politics-53315178 deployment in older adult care homes. 19 Jul 2021. https://www.gov.uk/government/consultations/making-vaccination-a-condition-of-deployment-in-older-adult-care-homes/making-vaccination-acondition-of-deployment-in-older-adult-care-homes

5 Public Health England. Covid-19 vaccination statistics week ending Sunday 18th July 2021. 22 Jul 2021. https://www.england.nhs.uk/statistics/wpcontent/uploads/sites/2/2021/07/COVID-19-weekly-announced-vaccinations-22-July-2021.pdf

6 Skills for Care. The state of the adult social care sector and workforce in England. Oct 2020. https://www.skillsforcare.org.uk/adult-social-careworkforce-data/Workforce-intelligence/publications/national-information/The-state-of-the-adult-social-care-sector-and-workforce-in-England.aspx Department of Health and Social Care. Making vaccination a condition of 
This article is made freely available for use in accordance with BMI's website terms and conditions for the duration of the covid-19 pandemic or until otherwise determined by BMJ. You may use, download and print the article for any lawful, non-commercial purpose (including text and data mining) provided

that all copyright notices and trade marks are retained. 